\title{
Pachydermoperiostosis (idiopathic hypertrophic osteoarthropathy)
}

\author{
Y. L. YU \\ M.B. B.S., M.R.C.P. \\ W. P. G. TURCK \\ M.B., Ch.B., F.R.C.P. \\ Department of Medicine, Alice Ho Miu Ling Nethersole Hospital, Hong Kong
}

\begin{abstract}
Summary
A Chinese patient with the incomplete form of pachydermoperiostosis is described. Brief comments on the diagnosis, familial occurrence and management are given.
\end{abstract}

\section{Introduction}

Pachydermoperiostosis is a syndrome characterized by finger clubbing, periosteal new bone formation especially over the distal ends of long bones, and coarsening of the facial features, with thickening, furrowing and oiliness of the skin of the face and forehead. The first reported cases were the Hagner brothers, who had typical features of this syndrome. They were first described by Friedreich (1868), and later by Erb (1887) and Virchow (1889), who diagnosed the condition as acromegaly. It was only $\mathbf{4 5}$ years ago that pachydermoperiostosis was first recognized as a distinct entity by Touraine, Solente and Golé (1935), and thus frequently referred to as 'Touraine-Solente-Golé syndrome'. It has since been reported from Europeans, Japanese (Ota, 1931), African Negroes (Findlay and Oosthuizen, 1951), American Negroes (Vogl and Goldfischer, 1962), Hindus (Carruthers, 1943) and South American Indians (Marroquin, 1941) but as far as the present authors are aware, only one case has been reported from a Chinese (Leong, $\mathrm{Ng}$ and Tay, 1976). They now report details of a second Chinese patient, the first such patient to be described from Hong Kong.

\section{Case report}

A 16-year-old male student first attended Nethersole Hospital in July 1976 complaining of painless enlargement of the tips of his fingers and toes for the past 3 years, with significant progression over the past year. On direct questioning, he admitted that his wrists and ankles had also become bigger. There was, however, no arthralgia or bone pain. He had been troubled by pimples on his cheeks for 7 months. He was the tallest and heaviest among existing members of his family. Family history of clubbing or arthralgia was negative. He was a non-smoker and had no respiratory symptoms. There was no history of headache or visual disturbance. Initially he had attended a clinic at another hospital, where the diagnosis of acromegaly had been made.
On examination, he measured $182 \mathrm{~cm}$ in height ( $>97$ th centile) and $66 \mathrm{~kg}$ in weight (95th centile). There was no cyanosis and secondary sexual characters were well developed. Hyperhidrosis was not present. His fingers and toes showed marked clubbing, giving rise to the typical spade-like hands and feet and the watch-glass nail plates (Fig. 1). His ankles and wrists were enlarged but without signs of arthritis. His forehead had prominent transverse folds and the naso-labial folds were deep, imparting an expression which was anxious and mature for his age (Fig. 2). The skin of the face was thickened, oily and pitted with scars of acne. There was however no thickening or furrowing of the scalp (cutis verticis gyrata). No other abnormal signs were noted.

The following investigations were within normal limits: haematological profile, ESR, blood urea, serum electrolytes, serum bilirubin, alkaline-phosphatase and transaminases, an oral glucose tolerance test extended up to $5 \mathrm{hr}$, serum calcium, inorganic phosphate and serum protein electrophoresis. VDRL test was negative. Serum thyroxine level was $120 \mathrm{nmol} / 1$ (normal 70-160 nmol/l). Fasting growth hormone was $1.01 \mu \mathrm{g} / \mathrm{l}$ (normal 1.0-10.0 $\mu \mathrm{g} / \mathrm{l}$ ). Chromosome study showed normal karyotype with XY sex chromosomes.

The radiological findings were of interest. X-ray of the hands and wrists (Fig. 3) revealed subperiosteal new bone formation at the 4th and 5th metacarpals and all proximal phalanges, with thickened cortical bone at the distal end of the ulnae. Soft tissue thickening and clubbing of fingers were also evident. X-ray of the feet and ankles showed thickened cortex of the metatarsals and proximal phalanges. Loss of normal contour and irregular thickening of cortical bone were present along the shaft of the fibulae and tibiae (Fig. 4). $\mathrm{X}$-rays of the chest, skull and heels were normal.

The diagnosis of pachydermoperiostosis was made on the basis of clinical and radiological findings, and reassurance given. Follow-up to date (June, 1980) showed no further progression of his condition.

\section{Discussion}

The age and sex of the patient, the gradual onset of symptoms, the clinical features of marked clubbing, 


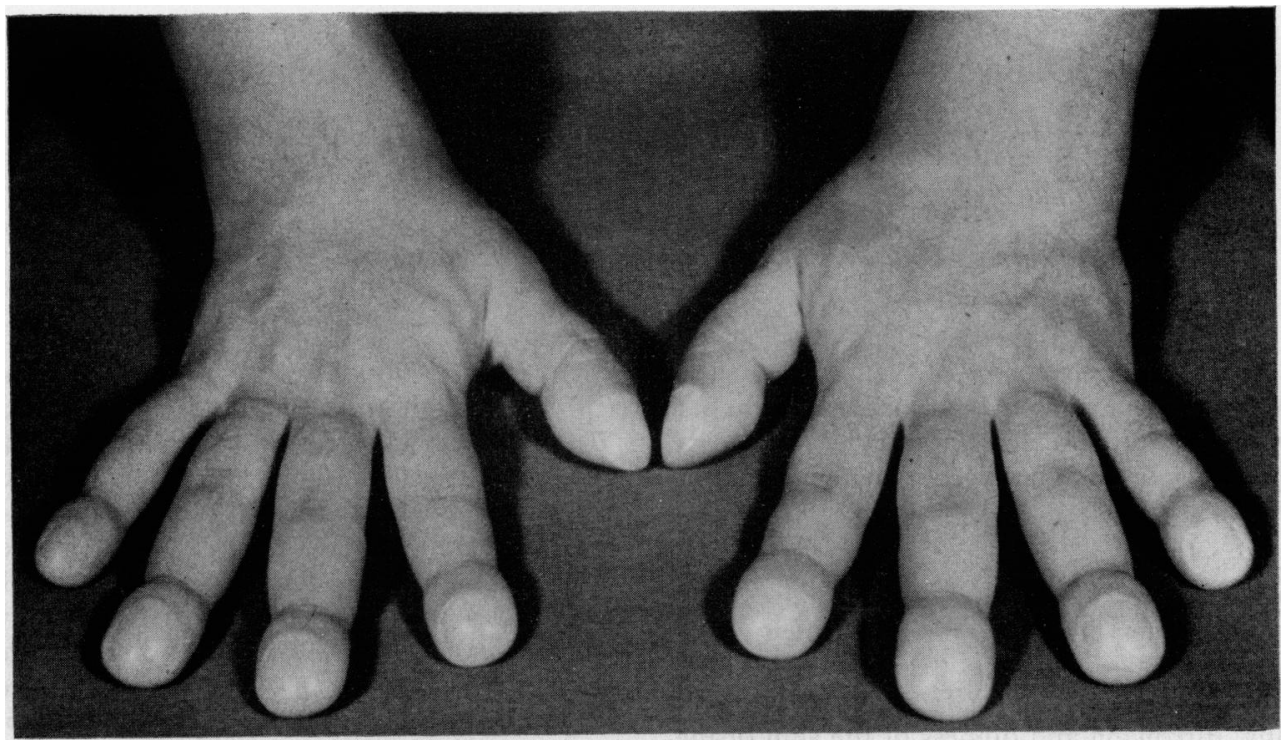

FIG. 1. Marked clubbing of fingers.

enlargement of distal ends of extremities and coarsening of facial features, suggest the diagnosis of pachydermoperiostosis (idiopathic hypertrophic osteoarthropathy). This is confirmed by the radiological picture of irregular subperiosteal new bone formation along the tubular bones. Touraine et al. (1935) distinguished 3 forms of this condition-the 'complete form' with pachydermia and pachyperiostosis; an 'incomplete form' without scalp involvement; and a 'forme fruste' in which clubbing and thickening of the face, scalp or both, are present, but periosteal changes are absent or minimal. In the absence of cutis verticis gyrata, the present patient fits into the 'incomplete form'.

Hypertrophic pulmonary osteoarthropathy, which also gives rise to clubbing and subperiosteal new bone formation, has to be excluded. It has long been considered that coarsening of facial features and scalp is diagnostic of idiopathic hypertrophic osteoarthropathy; however, this may also appear in association with intrathoracic tumours (Hammarsten and O'Leary, 1957). Thus, it is impossible to distinguish between these 2 forms of hypertrophic osteoarthropathy by the appearance of the patient alone. The features which point to the pulmonary form are: an older age of onset, an acute onset associated with pain in the extremities, and the presence of neoplastic or suppurative intrathoracic diseases.

To the unwary, the acromegaloid face may lead to the diagnosis of acromegaly or gigantism. However, a careful assessment will show that the soft tissue overgrowth is restricted to the extremities and the face, that the skeletal overgrowth is not generalizend and that the local and secondary hormonal effects of pituitary tumour are absent.

Other conditions which may cause confusiof in the diagnosis are thyroid acropachy, leprosy, rhe wimatoid arthritis, syphilitic periostitis and Pages. disease of bone.

Familial occurrence is common and has be observed in more than $50 \%$ of the reported cases. The disorder is inherited as an autosomal domina $\overrightarrow{\vec{m}} \mathrm{t}$ trait, with marked variability in expression, phen⿳亠口冋typically more severe in males (Rimion, 196 苼. Chromosomal abnormalities of XYY trisomy hape been observed in a patient and his son, both having idiopathic osteoarthropathy (Tzoneva-Maneva, Bosajieva and Petrov, 1966). Either simple herediary clubbing or cutis verticis gyrata can occur withing families and independently of pachydermopegostosis. It is possible that they may represent monosymptomatic forms of pachydermoperiostosis (Marroquin, 1941). In the present patient there wege no chromosomal abnormalities and there was family history of pachydermoperiostosis, clubbing or cutis verticis gyrata.

Pachydermoperiostosis has a self-limiting cours, and progression stops at the end of adolescence. There is no curative treatment for the skeletal $\bar{a} \overline{\mathrm{B}}$ normalities. Mild analgesics may be given for pain due to sub-periosteal new bone formation. F黑r correction of gross disfigurement, plastic and reconstructive surgery may be indicated. Otherwise, reassurance is all that is required. Clinical recogrittion of pachydermoperiostosis is important, sine 


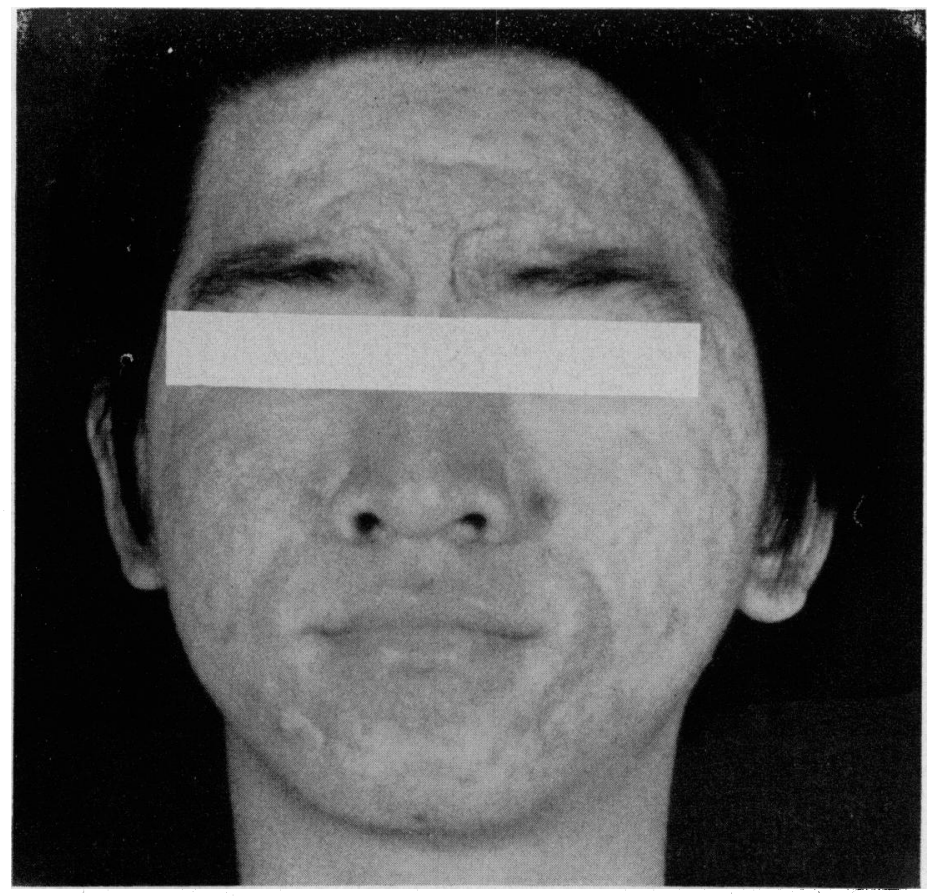

FIG. 2. Facial appearance, with thickened, oily and scarred skin, prominent naso-labial folds and transverse folds of the forehead.

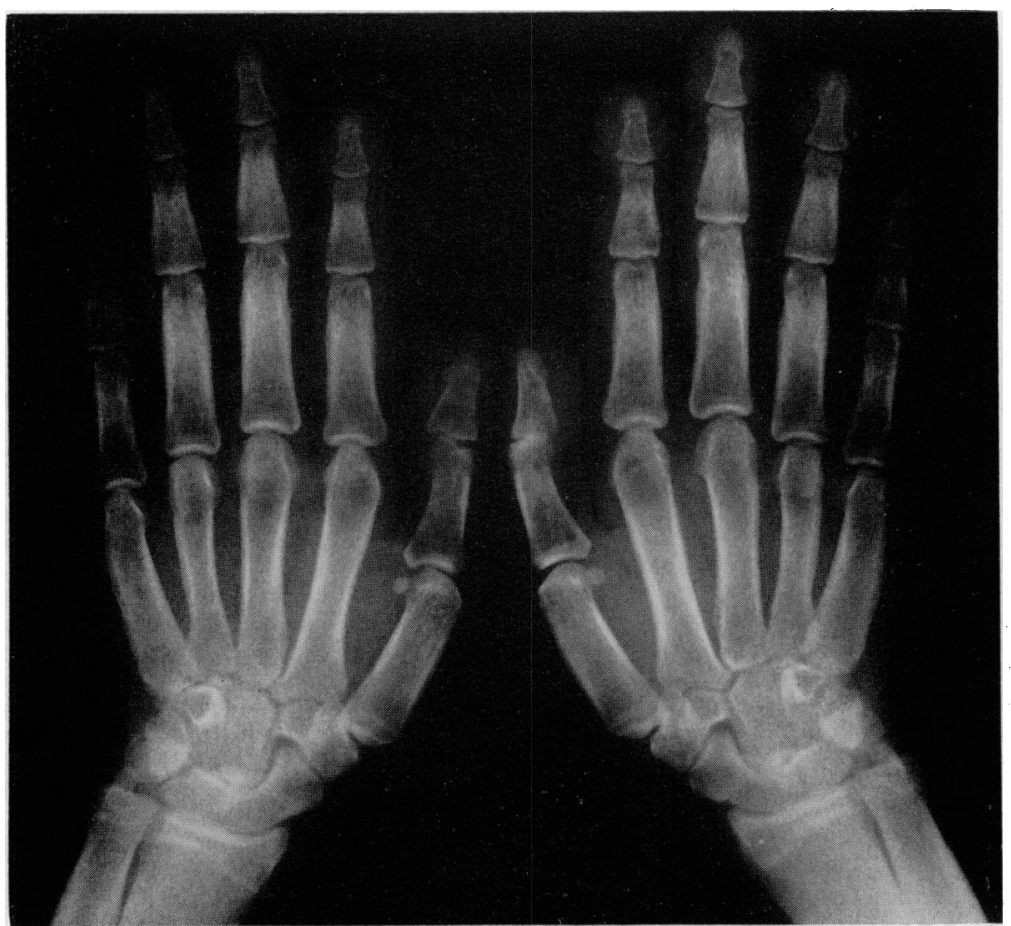

Fig. 3. Radiograph of hands and wrists showing subperiosteal new bone formation (see text). 


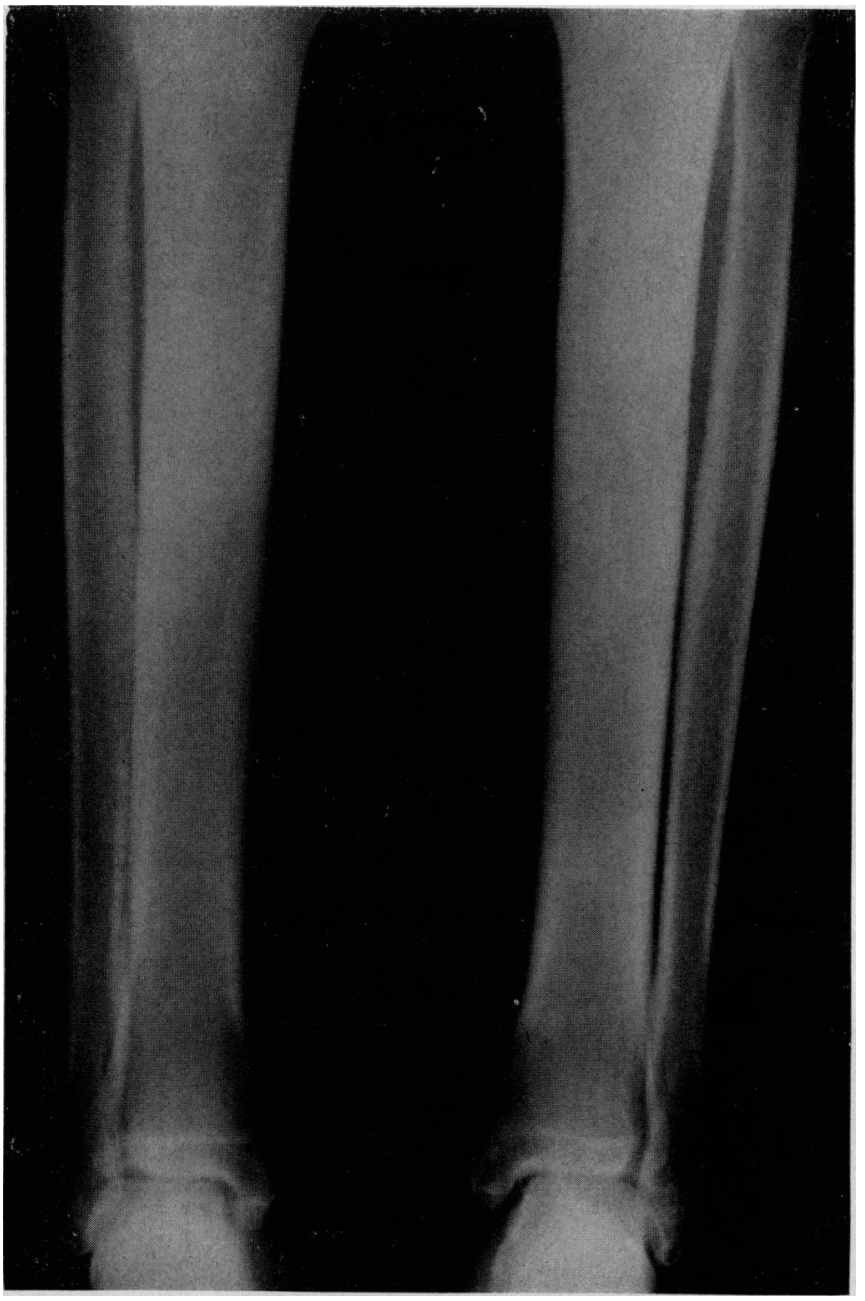

FIG. 4. Radiograph of legs showing irregular cortical thickening.

misdiagnosis may subject the patient to unnecessary investigation and worry.

\section{References}

Carruthers, L.B. (1943) Idiopathic hypertrophic osteoarthropathy familial in type. Journal of the Christian Medical Association of India, Burma and Ceylon, 18, 1.

ERB, W. (1887/88) Ueber Akromegalie (krankhaften Riesenwuchs). Deutsches Archiv für klinische Medizin, 42, 295.

Findlay, G.H. \& Oosthuizen, W.J. (1951) Pachydermoperiostosis (syndrome of Touraine, Solente and Golé). South African Medical Journal, 25, 747.

Friedreich, N. (1868) Hyperostose des gesammten Skelets. Virchows Archiv fiir pathologische Anatomie und Physiologie und fiir klinische Medizin, 43, 83.

Hammarsten, J.F. \& O'Leary, J. (1957) Features and significance of hypertrophic osteoarthropathy. Archives of Internal Medicine, 99, 431.

Leong, D., NG, F.C. \& TAY, C.H. (1976) Pachydermoperios- tosis (idiopathic hypertrophic osteoarthropathy). Singapgire Medical Journal, 17, 113.

Marroquin, J. (1941) El cuero cabelludo cerebroide 'Cha‥ rahuma' en al Andino. Revista de neuro-psiquiatria, 4, $2 b$

OтA, M. (1931) Cutis gyrata der Stirnhaut, besonders thr histologischer Befund. Dermatologische Wochenschrift, 345.

Rimion, D.L. (1965) Pachydermoperiostosis (idiopat clubbing and periostosis): genetic and physiologic copsiderations. New England Journal of Medicine, 272, 923

Touraine, A., Solente, G. \& Golé, L. (1935) Un syndrơ e ostéodermopathique: la pachydermie plicaturée a※oc pachypériostose des extrémités. Presse médicale, 43, 1820.

Tzoneva-Maneva, M.T., Bosajieva, E. \& Petrov, B. (1966) Chromosomal abnormalities in idiopathic osteoarthiopathy. Lancet, i, 1000.

VIRCHOW, R. (1889) Acromegaly. Illustrated Medical Ne:T's, 2, 241.

VoGl, A. \& Goldfischer, S. (1962) Pachydermoperiostoās, primary or idiopathic hypertrophic osteoarthropat席y. American Journal of Medicine, 33, 166. 